\section{Field Tests on the Herbicide Tolerance of Various Maize Genotypes}

\author{
Péter Bónis - Tamás Árendás - \\ Lajos Csaba Marton \\ Agricultural Research Institute of the Hungarian Academy of \\ Sciences, Martonvásár
}

\section{SUMMARY}

Investigations were made in Martonvásár on the herbicide tolerance of 22 inbred maize lines and 3 parental single crosses when treated with one herbicide applied after sowing, prior to emergence, and with seven applied post-emergence in the 6-8-leaf stage. Visible damage was scored 14 days after the treatment.

An analysis of the phytotoxic effects led to the conclusion that a single dose of the tested herbicides did not cause any damage to the genotypes investigated, with the exception of one inbred line, which was extremely sensitive to herbicides of the sulphonyl carbamide type and moderately sensitive to both rates of dicamba. In many cases, a double dose of the herbicides caused mild or moderate symptoms on the maize lines.

\section{INTRODUCTION}

A quarter of the arable land in Hungary is occupied by maize. The climate and soil conditions make the country ideally suitable for field seed production. Depending on the demand, the necessary quantity of maize seed is grown on an area of 20,00040,000 hectares each year. As is well known, the inbred lines used for the production of hybrid maize seed respond more sensitively to external environmental effects than the hybrids produced by crossing them. This greater sensitivity is manifested both in their habits and in their response to various stress factors. Inbred lines can only compete successfully for light, water, nutrients and carbon dioxide if they are adequately protected against their chief rivals, weeds. In order to keep the weed cover below the danger threshold, all possible means must be employed, including crop rotation, the use of a cultivator between the rows, and the application of herbicide. The use of chemicals is an important component of integrated weed management. The ever widening choice of herbicides and maize hybrids necessitates regular herbicide tolerance tests on maize hybrids and their parental lines.

For hybrid maize seed production, it is advisable to choose areas where there are no troublesome perennial weeds (Kádár, 1997). In practice, however, to ensure the required isolation distance and due to the needs of crop rotation, seed multiplication fields are often found on areas heavily infested with weeds, where weed control can only be achieved with special post-emergence herbicides that are less selective.

Many authors have reported on the different herbicide tolerance levels of various inbred maize lines. Eastin et al. (1964), Palmer and Grogan (1966) and Shimabukuro et al. (1971) observed sensitivity responses in maize lines after treatment with atrazine, an active agent considered to be superselective for maize. Berzsenyi et al. (1994, 1997), Rowe and Penner (1990), Rowe et al. (1990) and Narsaiah and Harvey (1977) noted differences in the tolerance of inbred lines when testing with chloroacetanilides. Of 10 tested maize genotypes, Eberlein et al. (1989) found 3 to be very sensitive, 3 very tolerant and 4 moderately sensitive to herbicides belonging to the sulphonyl carbamide group. Green (1998), Green and Ulrich (1993, 1994), Harms et al. (1990), Kang (1993) and Widstrom and Dowler (1995) also reported that inbred lines exhibited different sensitivity responses after treatment with herbicides in the sulphonylurea group. When testing sulphonyl carbamides and other types of herbicides, Molnár et al. (2001) found that the response of maize hybrids to various active agents depended on their genetic backgrounds.

Due to this great diversity in the herbicide responses of different maize genotypes, the present experiments were aimed at testing the most important parental components in commercial Martonvásár maize hybrids for their tolerance to one preemergence and several post-emergence herbicides.

\section{MATERIALS AND METHODS}

Investigations were made in 2002 on the tolerance of 22 inbred maize lines and 3 parental single crosses grown on chernozem soil with forest residues (Calciustoll) in Martonvásár to one herbicide applied pre-emergence and 7 applied postemergence. The experiment was set up in a twofactor split-plot design with two replications, with an untreated control plot for each treatment. The active agents in these herbicides were as follows: flumioxazine, mezotrion, foramsulphuron + isoxadiphen-ethyl, foramsulphuron + isoxadiphenethyl + iodosulphuron-methyl-Na, rimsulphuron, nicosulphuron, dicamba, rimsulphuron + tiphensulphuron-methyl. Of these herbicides, only mezotrion is authorised for use in maize seed production. However, due to the frequent appearance and multiplication of many troublesome weeds on seed production fields, it is important to test herbicides that are at present only authorised for use on fields sown for grain and silage, but which are effective against one or more of the troublesome weed species (such as Sorghum halepense, Elymus repens, Abuthilon theophrasti). One of the herbicides was sprayed after sowing, prior to emergence, while the other seven were applied post-emergence, in the 6-8-leaf stage of maize, using the maximum dose permitted in the licence and double this dose. The 
pre-emergence treatment was carried out 2 days after sowing. Shortly after spraying, $10 \mathrm{~mm}$ rain fell, followed by a further $5 \mathrm{~mm}$ over the next 2 weeks. No excessively hot days with temperatures of above $30^{\circ} \mathrm{C}$ were recorded prior to the post-emergence treatment or for the following 10 days, but on one of the days before treatment the minimum temperature dropped to below $10^{\circ} \mathrm{C}$, exposing the maize plants to cold stress. This could have influenced the development of phytotoxic symptoms in the case of herbicides of the sulphonyl carbamide type. During the course of the vegetation period, visible phytotoxic damage was scored 14 days after the treatment using a $0-100$ scale on which 0 indicated undamaged and 100 killed plants. The phytotoxicity percentage combines the number of killed plants and the extent of leaf damage due to scorching in a single parameter.

\section{RESULTS}

Averaged over the inbred lines and parental single crosses, the damage did not exceed the mildmoderate level (5\%) when the single dose was applied. Genotypes treated with mezotrion remained symptom-free. Based on the increasing severity of the symptoms the compounds can be ranked as follows: mezotrion $\leq$ dicamba $\leq$ flumioxazine < foramsulphuron + isoxadiphen-ethyl + iodosulphuron-methyl-Na $\leq$ foramsulphuron + isoxadiphen-ethyl $\leq$ nicosulphuron $\leq$ rimsulphuron $\leq$ rimsulphuron + tiphensulphuron-methyl. The sign $\leq$ was used when there was no significant difference between the compounds as regards the extent of damage. At the double rate, due to the different interactions between the herbicides and the genotypes, this order was modified in places. Mezotrion still caused the significantly lowest extent of damage, which was not significantly different from that caused by the single dose (Table 1). Averaged over the lines, the double dose of the compound containing flumioxazine induced the most severe symptoms, leading to a moderate level of damage $(\sim 20 \%)$ in the case of two lines.

Averaged over the herbicides, the various lines were well able to tolerate normal doses of the herbicides (Table 2). One inbred line exhibited extreme sensitivity to herbicides of the sulphonyl carbamide type and was completely destroyed by both doses. This same line exhibited moderate to severe symptoms $(25-32.5 \%)$ when treated with dicamba (Table 3).

\section{REFERENCES}

Berzsenyi， Z.-Bónis, P.-Árendás, T.-Berényi， Gy. (1994): Comparative investigations on the efficacy and selectivity of different herbicides in maize. Z. Pflkrankh. Pflshutz. Sonderh., 14. 457-466.

Berzsenyi，Z.-Győrffy， B.-Árendás，T.-Bónis，P.-Lap， D. Q. (1997): Studies on the phytotoxicity of herbicides in maize (Zea mays L.) as affected by temperature and antidotes. Acta Agron. Hung., 45. 443-448.

Eastin, E. F.-Palmer, R. D.-Grogan, C. O. (1964): Mode of action of atrazine and simazine in susceptible and resistant lines of corn. Weeds, 12. 49-52.

Eberlein, C. V.-Rosow, K. M.-Geadelmann, J. L.-Openshaw, S. J. (1989): Differential tolerance of corn genotypes to DPXM6316. Weed Sci., 37. 651-657.

Green, J. M. (1998): Differential tolerance of corn (Zea mays) inbreds to four sulfonylurea herbicides and bentazon. Weed Technol., 12. 474-477.

Green, J. M.-Ulrich, J. F. (1993): Response of corn (Zea mays) inbreds and hybrids to sulfonylurea herbicides. Weed Sci., 41. 208-516.

Green, J. M.-Ulrich, J. F. (1994): Response of maize (Zea mays) inbreds and hybrids to rimsulfuron. Pestic. Sci., 40. 187-191.

Harms, C. T.-Montoya, A. L.-Privalle, L. S.-Riggs, R. W. (1990): Genetic and biochemical characterization of corn inbred lines tolerant to sulfonylurea herbicide primisulfuron. Theor. Appl. Genet., 80. 353-358.
Kádár, A. (1997): Vegyszeres gyomirtás és termésszabályozás gyakorlata. (Chemical weed control and yield regulation.) Faktum BT, Budapest, 406.

Kang, M. S. (1993): Inheritance of susceptibility of nicosulfuron herbicide in maize. J. Heredity., 84. 216-217.

Molnár, I.-Tóth, E.-Somlyay, I.-Pakurár, M. (2001): Környezeti tényezők hatása a kukoricahibridek herbicidérzékenységére. (Effects of environmental conditions for sensitivity of corn cultivars to herbicide treatments.) Növényvéd., 37. 483-489.

Narsaiah, D. B.-Harvey, R. G. (1977): Differential responses of corn inbreds and hybrids to alachlor. Crop Sci., 17. 657-659.

Palmer, R. D.-Grogan, C. O. (1966): Tolerance of corn lines to atrazine in relation to content of benzoxazinone derivate, 2glucoside. Weeds, 14. 219-222.

Rowe, L.-Penner, D. (1990): Factors affecting chloroacetanilide injury to corn (Zea mays).Weed Technol., 9. 904-906.

Rowe, L.-Rossmann, E.-Penner, D. (1990): Differential response of corn hybrids and inbreds to metolachlor. Weed Sci., 38. 563-566.

Shimabukuro, R. H.-Frear, D. S.-Swanson, H. R.-Walsh, W. C. (1971): Glutathione conjugation an enzimatic basis for atrazine resistance in corn. Plant Physiol., 47. 10-14.

Widstrom, N. W.-Dowler, C. D. (1995): Sensitivity of selected field corn (Zea mays) to nicosulfuron. Weed Technol., 9. 779782 .

Table 1

Extent of phytotoxic damage (\%), averaged over the genotypes, in a herbicide tolerance experiment

\begin{tabular}{|l|r|r|r|r|r|r|r|}
\hline & Flumioxazine & Mezotrion & $\begin{array}{c}\text { Foramsulphuron } \\
\text { + Isoxadifen }\end{array}$ & $\begin{array}{c}\text { Foramsulphuron } \\
+ \text { Iodosulphron } \\
\text { + Isoxadifren }\end{array}$ & Rimsulphuron & Nicosulphuron & Dicamba \\
+ Tiphensulph. \\
\hline Single dose
\end{tabular}


Extent of phytotoxic damage (\%) exhibited by the tested genotypes, averaged over the herbicide treatments

\begin{tabular}{|c|c|c|c|c|c|c|c|c|c|c|c|c|c|c|c|c|c|c|c|c|c|c|c|c|c|}
\hline & \multicolumn{25}{|c|}{ Line numbers } \\
\hline & 1 & 2 & 3 & 4 & 5 & 6 & 7 & 8 & 9 & 10 & 11 & 12 & 13 & 14 & 15 & \begin{tabular}{|l|l|}
16 \\
\end{tabular} & 17 & \begin{tabular}{|l|}
18 \\
\end{tabular} & 19 & 20 & 21 & 22 & \begin{tabular}{|l|l|}
23 \\
\end{tabular} & \begin{tabular}{|l|l|}
24 \\
\end{tabular} & 25 \\
\hline Single dose & 0.6 & 0.6 & 0.0 & 0.0 & \begin{tabular}{|l|}
0.0 \\
\end{tabular} & 0.0 & 2.8 & 0.6 & 0.0 & 53.8 & 0.0 & 0.0 & 0.6 & 0.0 & 0.0 & 1.3 & 0.0 & 0.0 & 0.6 & 0.0 & 0.0 & \begin{tabular}{|l|}
0.6 \\
\end{tabular} & \begin{tabular}{|l|}
0.0 \\
\end{tabular} & 1.9 & 2.2 \\
\hline Double dose & 3.4 & 8.4 & 4.7 & 1.6 & 4.7 & 4.1 & 8.4 & 3.1 & 1.6 & 59.4 & 0.6 & 4.1 & 2.5 & 0.6 & 1.3 & 9.1 & 0.6 & 0.0 & 3.8 & 0.9 & 1.6 & 2.8 & \begin{tabular}{|l|}
0.9 \\
\end{tabular} & 3.8 & 5.6 \\
\hline Mean & 2.0 & 4.5 & 2.3 & 0.8 & 2.3 & 2.0 & 5.6 & 1.9 & 0.8 & 56.6 & 0.3 & 2.0 & 1.6 & 0.3 & 0.6 & 5.2 & 0.3 & 0.0 & 2.2 & 0.5 & 0.8 & 1.7 & 0.5 & 2.8 & 3.9 \\
\hline
\end{tabular}

Table 3

Phytotoxic damage (\%) caused by herbicide treatments in different genotypes

\begin{tabular}{|c|c|c|c|c|c|c|c|c|c|c|c|c|c|c|c|c|c|c|c|c|c|c|c|c|c|c|}
\hline \multirow{2}{*}{ Herbicide } & \multirow{2}{*}{ Dose } & \multicolumn{25}{|c|}{ Line numbers } \\
\hline & & 1 & 2 & 3 & 4 & 5 & 6 & 7 & 8 & 9 & 10 & 11 & 12 & 13 & 14 & 15 & 16 & 17 & 18 & 19 & 20 & 21 & 22 & 23 & 24 & 25 \\
\hline \multirow{2}{*}{ Flumioxazine } & single & 5.0 & 0.0 & 0.0 & 0.0 & 0.0 & 0.0 & 0.0 & 5.0 & 0.0 & 0.0 & 0.0 & 0.0 & 5.0 & 0.0 & 0.0 & 5.0 & 0.0 & 0.0 & 5.0 & 0.0 & 0.0 & 0.0 & 0.0 & 10.0 & 0.0 \\
\hline & double & 12.5 & 17.5 & 12.5 & 12.5 & 15.0 & 5.0 & 10.0 & 15.0 & 7.5 & 12.5 & 0.0 & 10.0 & 15.0 & 5.0 & 5.0 & 15.0 & 0.0 & 0.0 & 15.0 & 0.0 & 5.0 & 7.5 & 0.0 & 17.5 & 0.0 \\
\hline \multirow{2}{*}{ Mezotrion } & single & 0.0 & 0.0 & 0.0 & 0.0 & 0.0 & 0.0 & 0.0 & 0.0 & 0.0 & 0.0 & 0.0 & 0.0 & 0.0 & 0.0 & 0.0 & 0.0 & 0.0 & 0.0 & 0.0 & 0.0 & 0.0 & 0.0 & 0.0 & 0.0 & 0.0 \\
\hline & double & 5.0 & 7.5 & 0.0 & 0.0 & 0.0 & 0.0 & 0.0 & 0.0 & 0.0 & 5.0 & 0.0 & 0.0 & 0.0 & 0.0 & 0.0 & 10.0 & 0.0 & 0.0 & 0.0 & 0.0 & 0.0 & 0.0 & 0.0 & 0.0 & 0.0 \\
\hline \multirow{2}{*}{$\begin{array}{l}\text { Foramsulphuron } \\
\text { + Isoxadifen }\end{array}$} & single & 0.0 & 0.0 & 0.0 & 0.0 & 0.0 & 0.0 & 7.5 & 0.0 & 0.0 & 80.0 & 0.0 & 0.0 & 0.0 & 0.0 & 0.0 & 0.0 & 0.0 & 0.0 & 0.0 & 0.0 & 0.0 & 0.0 & 0.0 & 0.0 & 0.0 \\
\hline & double & 0.0 & 15.0 & 7.5 & 0.0 & 5.0 & 0.0 & 17.5 & 10.0 & 0.0 & 85.0 & 0.0 & 12.5 & 0.0 & 0.0 & 0.0 & 0.0 & 0.0 & 0.0 & 0.0 & 0.0 & 0.0 & 5.0 & 0.0 & 0.0 & 5.0 \\
\hline \multirow{2}{*}{$\begin{array}{l}\text { Foramsulphuron } \\
\text { + Iodosulphron } \\
\text { + Isoxadifren }\end{array}$} & single & 0.0 & 5.0 & 0.0 & 0.0 & 0.0 & 0.0 & 0.0 & 0.0 & 0.0 & 70.0 & 0.0 & 0.0 & 0.0 & 0.0 & 0.0 & 0.0 & 0.0 & 0.0 & 0.0 & 0.0 & 0.0 & 0.0 & 0.0 & 5.0 & 5.0 \\
\hline & double & 5.0 & 5.0 & 0.0 & 0.0 & 5.0 & 7.5 & 5.0 & 0.0 & 5.0 & 75.0 & 0.0 & 0.0 & 0.0 & 0.0 & 0.0 & 0.0 & 0.0 & 0.0 & 0.0 & 0.0 & 0.0 & 0.0 & 0.0 & 7.5 & 7.5 \\
\hline \multirow{2}{*}{ Rimsulphuron } & single & 0.0 & 0.0 & 0.0 & 0.0 & 0.0 & 0.0 & 5.0 & 0.0 & 0.0 & 90.0 & 0.0 & 0.0 & 0.0 & 0.0 & 0.0 & 0.0 & 0.0 & 0.0 & 0.0 & 0.0 & 0.0 & 0.0 & 0.0 & 0.0 & 0.0 \\
\hline & double & 5.0 & 0.0 & 0.0 & 0.0 & 5.0 & 0.0 & 10.0 & 0.0 & 0.0 & 90.0 & 5.0 & 0.0 & 0.0 & 0.0 & 0.0 & 10.0 & 5.0 & 0.0 & 0.0 & 0.0 & 0.0 & 0.0 & 0.0 & 0.0 & 5.0 \\
\hline \multirow{2}{*}{ Nicosulphuron } & single & 0.0 & 0.0 & 0.0 & 0.0 & 0.0 & 0.0 & 0.0 & 0.0 & 0.0 & 82.5 & 0.0 & 0.0 & 0.0 & 0.0 & 0.0 & 5.0 & 0.0 & 0.0 & 0.0 & 0.0 & 0.0 & 5.0 & 0.0 & 0.0 & 0.0 \\
\hline & double & 0.0 & 0.0 & 5.0 & 0.0 & 0.0 & 0.0 & 0.0 & 0.0 & 0.0 & 85.0 & 0.0 & 0.0 & 0.0 & 0.0 & 0.0 & 15.0 & 0.0 & 0.0 & 0.0 & 0.0 & 0.0 & 10.0 & 7.5 & 0.0 & 0.0 \\
\hline \multirow{2}{*}{ Dicamba } & single & 0.0 & 0.0 & 0.0 & 0.0 & 0.0 & 0.0 & 0.0 & 0.0 & 0.0 & 22.5 & 0.0 & 0.0 & 0.0 & 0.0 & 0.0 & 0.0 & 0.0 & 0.0 & 0.0 & 0.0 & 0.0 & \begin{tabular}{|l|} 
\\
\end{tabular} & 0.0 & 0.0 & 5.0 \\
\hline & double & 0.0 & 12.5 & 0.0 & 0.0 & 7.5 & 15.0 & 10.0 & 0.0 & 0.0 & 32.5 & 0.0 & 5.0 & 0.0 & 0.0 & 5.0 & 15.0 & 0.0 & 0.0 & 0.0 & 7.5 & 7.5 & 0.0 & 0.0 & 0.0 & 12.5 \\
\hline \multirow{2}{*}{$\begin{array}{l}\text { Rimsulph. } \\
\text { + Tiphensulph. }\end{array}$} & single & 0.0 & 0.0 & 0.0 & 0.0 & 0.0 & 0.0 & 10.0 & 0.0 & 0.0 & 85.0 & 0.0 & 0.0 & 0.0 & 0.0 & 0.0 & 0.0 & 0.0 & 0.0 & 0.0 & 0.0 & 0.0 & 0.0 & 0.0 & 0.0 & 7.5 \\
\hline & double & 0.0 & 10.0 & 12.5 & 0.0 & 0.0 & 5.0 & 15.0 & 0.0 & 0.0 & 90.0 & 0.0 & 5.0 & 5.0 & 0.0 & 0.0 & 7.5 & 0.0 & \begin{tabular}{|l|}
0.0 \\
\end{tabular} & 15.0 & 0.0 & 0.0 & 0.0 & 0.0 & 5.0 & 15.0 \\
\hline
\end{tabular}

